\title{
Araçatuba Formation: palustrine deposits from the initial sedimentation phase of the Bauru Basin
}

\author{
LUIZ A. FERNANDES ${ }^{1}$, PAULO C. F. GIANNINI ${ }^{2}$ and ANA MARIA GÓES ${ }^{3}$ \\ ${ }^{1}$ Universidade Federal do Paraná - UFPR, Setor de Ciências da Terra, Departamento de Geologia \\ Centro Politécnico, Jardim das Américas, Caixa Postal 19001, 81531-990 Curitiba, PR, Brasil \\ ${ }^{2}$ Universidade de São Paulo - USP, Instituto de Geociências, Departamento de Geologia Sedimentar \\ e Ambiental Butantã, 05422-970 São Paulo, SP, Brasil \\ ${ }^{3}$ Universidade Federal do Pará - UFPA, Campus Universitário, Centro de Geociências \\ Caixa Postal 1611, 66075-900 Belém, PA, Brasil
}

Manuscript received on October 4, 2001; accepted for publication on October 25, 2002; presented by MOACYR V. COUTINHO

\begin{abstract}
The Bauru Basin (Upper Cretaceous) accumulated an essentially sandy continental sedimentary sequence. In a first desertic phase the basaltic substratum was covered by a widespread and homogeneous aeolian sand unit with minor loess intercalations. The substratum relief favored the formation of an endorheic drainage system under semi-arid climate, a process that started the development of the Araçatuba Paleoswamp. The palustrine deposits (Araçatuba Formation) comprise siltstone and tipically greenish gray narrow tabular strata of sandstone cemented by carbonate. Moulds and gypsite and dolomite pseudomorphs were identified. The moulds seem to be genetically associated with desiccation cracks, root marks and climbing ripple lamination levels, that, on the whole, indicate calm shallow saline waters undergoing phases of subaerial exposition. At the boundaries of the study area, sand units may exhibit sigmoidal features and convolute bedding structure, which is characteristic of marginal deltaic deposits. The Araçatuba Formation is enclosed in and later overlaid by the aeolian deposits of the Vale do Rio do Peixe Formation.
\end{abstract}

Key words: Araçatuba, Cretaceous, Bauru, swamp, palustrine, continental.

\section{INTRODUCTION}

The Araçatuba Formation spreads over the mid-west of São Paulo State, along the valleys of the Tietê, Aguapeí and Feio rivers, and their tributaries, in the Araçatuba region (Figure 1). This formation belongs to the lower part of the Bauru Group, which, together with the Caiuá Group, forms the Upper Cretaceous Sedimentary Sequence (Figure 2). This succession filled the Bauru Basin, a depression developed by the subsidence of the South American

Correspondence to: Luiz A. Fernandes

E-mail: lufernandes@ufpr.br
Platform southern-central part due to the accumulation of an almost 2000m thick layers of basaltic lava. This intracratonic basin was formed during the Upper Cretaceous, after the split of the Gondwana Continent. Once the Lower Cretaceous volcanic activities came to an end, the area where the basin would ultimately set remained exposed until, during the Upper Cretaceous, a relative subsidence dropped the base level and allowed the accumulation and preservation of interior sediments. The basin was filled with an essentially sandy sedimentary succession, with an average a thickness of 100 to 200 meters, which is currently preserved and spread out 
in an area of roughly $370,000 \mathrm{~km}^{2}$. The maximum thickness recorded for the sequence is 320 meters (Mezzalira et al. 1981).

The basement consists of Lower Cretaceous Serra Geral Formation volcanic rocks (mainly basalts), from which the sedimentary succession is separated by an erosive regional surface (nonconformity). Its upper erosive limit is demarcated by the Sul-Americana (King 1956) / Japi Surface (Almeida 1964) or by the posterior dissection of this surface.

\section{THE ARAÇATUBA UNIT}

The knowledge regarding the sedimentary succession which composed the sedimentary filling of the Bauru Basin evolved in four main phases as listed by Fernandes (1998): 1) pioneer phase (1905 to the early forties); 2) characterization phase (fifties and sixties); 3) lithostratigraphic regional mapping phase (seventies and early eighties); and 4) current phase.

The name Araçatuba that appeared during the regional cartography (phase 3 ) was previously used by Suguio et al. (1977) to designate a lithofacies (facies association) in the former Bauru Formation. Zaine et al. (1980, Paulipetro Report BP-014/80, unpublished) singled out a unit which they called Araçatuba Formation, in an unpublished report of regional mapping. The author, however, did not formally define the unit. Soares et al. (1979) outlined a proposal for the São Paulo State Cretaceous units where the Bauru unit was introduced as a group composed of four formations corresponding to the following units: a) Caiuá Formation; b) Santo Anastácio Facies; c) the assemblage: Lithofacies Araçatuba-Taciba Facies-Ubirajara Facies; d) Marília Lithofacies or Formation. Soares et al. (1980) formally defined the Bauru Group as composed of the Caiuá, Santo Anastácio, Adamantina and Marília formations. Almeida et al. (1980) adopted the Soares et al. (1979) proposition and divided the Adamantina Formation into five units for mapping purposes. Suguio (1981), when covering the paleoenvironmental and paleogeographic aspects of the
Bauru Group, brought back the designation Araçatuba and subdivided the group into six formations: Caiuá, Santo Anastácio, Araçatuba, São José do Rio Preto, Uberaba and Marília. Fernandes and Coimbra $(1994,1996)$ divided the "Neocretaceous suprabasaltic sequence" into two partially coeval groups: Caiuá (Paraná River, Goio Erê and Santo Anastácio formations) and Bauru (Uberaba, Adamantina and Marília formations; besides the Taiúva Analcimites).

The Araçatuba Formation (Fernandes and Coimbra 1998, 2000a), conception adopted here, corresponds partially to the Araçatuba Lithofacies of Suguio et al. (1977), and also partially to the Araçatuba Formation of Suguio (1981), Araçatuba Formation of Zaine et al. (1980, unpublished); and Adamantina Formation's KaIII unit, of Almeida et al. (1980).

\section{CHARACTERIZATION OF THE ARAÇATUBA FORMATION}

The Araçatuba unit presents a maximum thickness of 70 meters (Brandt Neto 1977, Zaine et al. 1980, unpublished), and is well exposed on cuts of the Marechal Rondon highway (SP 300) in the Araçatuba region. The unit is composed by siltstones and very fine sandstones, exhibiting a characteristic greenish-gray color. These are arranged in tabular beds of massive aspect and are usually centimeters to decimeters thick, but may reach 1 meter (Figure $3 a$ and $b$ ). At the boundaries of the occurrence area, the sandy strata may display sigmoidal shapes (Figure 3c). The strata makeup is composed of submetric overlapping sandy bodies, in vertical successions that go up to 7 meters. Boundaries and/or internal low angle sigmoidal bedding can also be observed (e.g. highway BR 153, km 112.5). The sigmoidal features correspond to approximate longitudinal sections of amalgamated lobes.

Carbonatic cement is a frequent component of the sandstone in the Araçatuba Formation and occurs frequently as horizontal tabular crusts running parallel to the rock-bedding. Despite the general massive appearance, the layers can show discreet 


\section{Bauru Basin localization}

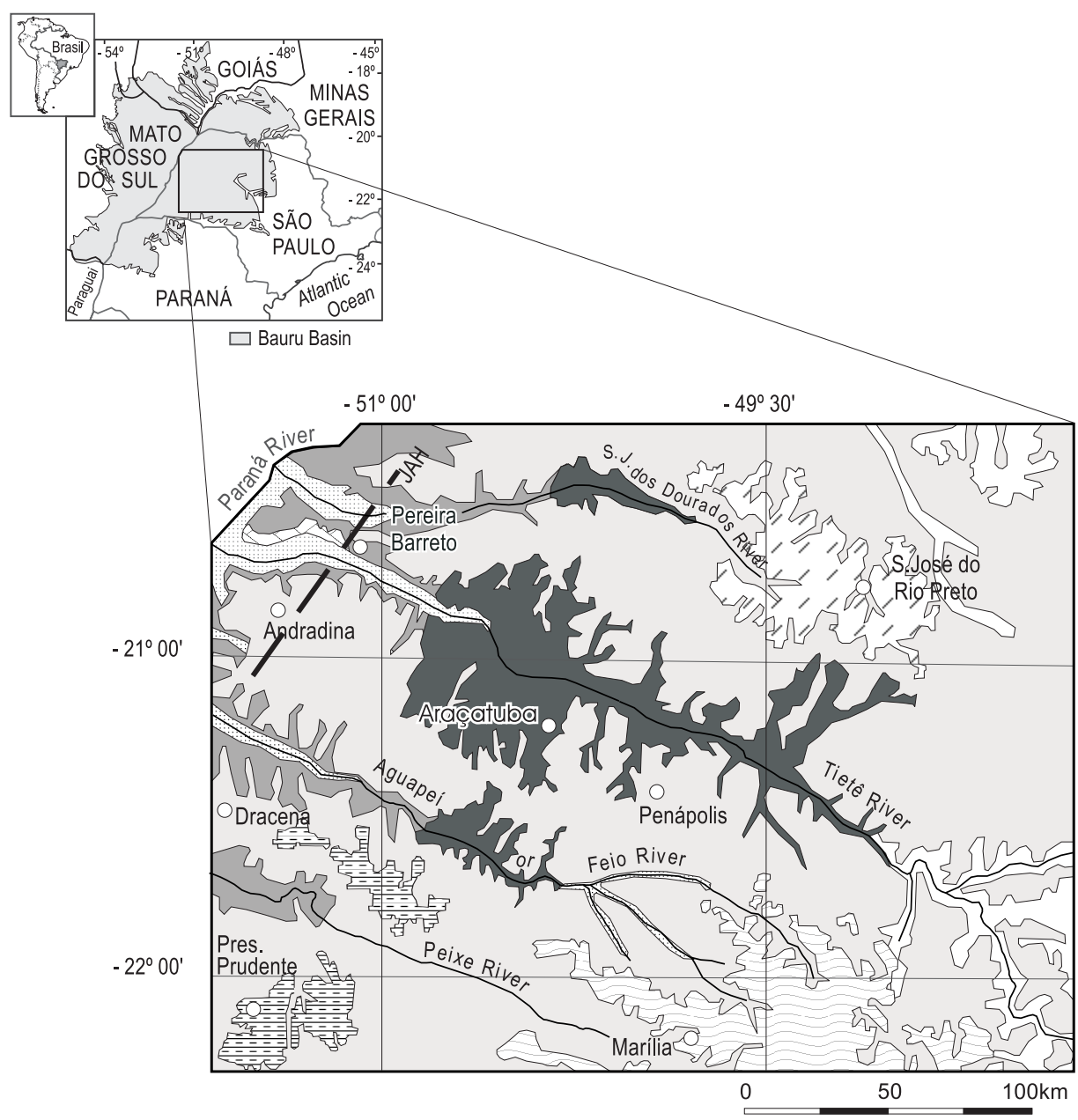

KEY: 1.Serra Geral Fm. (uK basement); 2. Rio Paraná Fm. and 3.Santo Anastácio Fm. (Caiuá Gr.); 4. Vale do Rio do Peixe Fm., 5. Araçatuba Fm., 6. Presidente Prudente Fm., 7. São José do Rio Preto Fm. and 8. Marília Fm. (Bauru Gr.); 9. Quaternary deposits; JAH = Jales-Andradina High. (After Fernandes and Coimbra 2000).

Fig. 1 - Geologic map of the study region and localization of the Bauru Basin (after Fernandes 1998).

normal grading to the top and parallel bedding at the top. Molds and radial-fibrous pseudomorphic gypsite crystals as well as probable dolomite pseu- domorphs were observed (Figure 3d, e and f). Mud cracks, root casts and dish structures are rather common in the unit (Figure $4 a$ and $b$ ). 


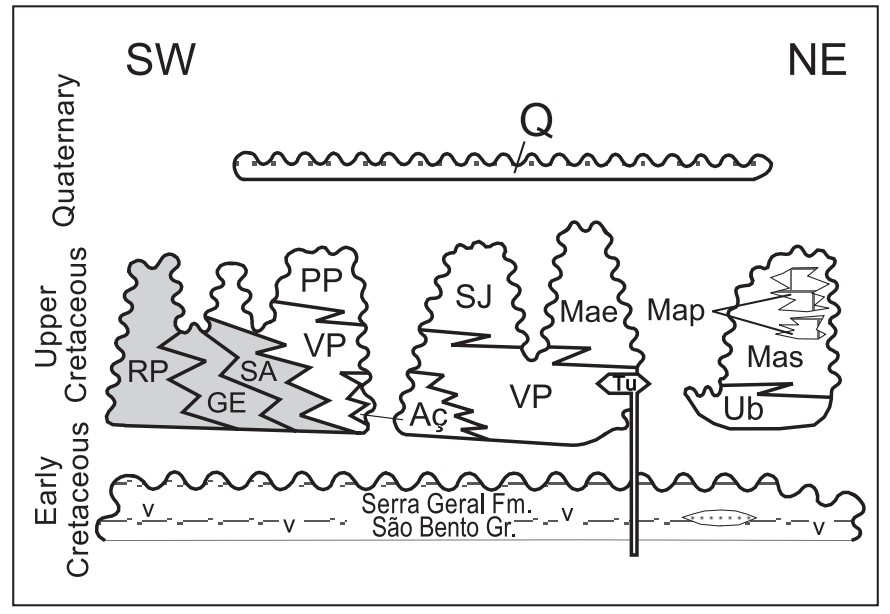

\begin{abstract}
Key: $\square$ Caiuá Gr.: RP=Rio Paraná Fm., GE=Goio Erê Fm. and SA=Santo Anastácio Fm.; $\square$ Bauru Gr.: VP=Vale do Rio do Peixe Fm., Aç=Araçatuba Fm., Ub=Uberaba Fm., $\mathbf{P P}=$ Presidente Prudente Fm., SJ=São José do Rio Preto Fm.,

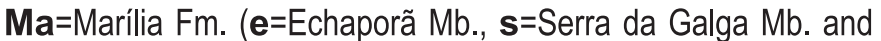
p=Ponte Alta Mb.); Tu=Taiúva Analcimites. (After Fernandes and Coimbra 2000).
\end{abstract}

Fig. 2 - Stratigraphic chart of the Bauru Basin (after Fernandes and Coimbra 2000a).

Saline crystal molds of the "desert roses" type have been described by Mezzalira (1974) on core samples from holes drilled at Santo Anastácio and Mirante do Paranapanema. Etchebehere et al. (1991) also describe several millimetric rhombshaped molds and some centimetric radial fibrous structures in the Tietê River valley, east of Araçatuba. They were interpreted as probable gypsite crystal molds. Fernandes (1998) reported the finding of radial fibrous crystal molds with diameters ranging from 5 to 10 centimeters, in road cuts of the SP 300 (km 548.5; Araçatuba), SP 461 (km 40.1; Brejo Alegre) and SP 304 (close to km 412) highways. In the last one crystal molds occur one centimeter above root casts, a fact that suggests phases exposure. At the entrance to Brejo Alegre, laminated pelites contain crystal molds interlaid with crosslaminated siltstones (traction structures from a tranquil flow regime). Such features characterize saline shallow calm water during periods of drought. Mud cracks have been observed in a lateral road pave- ment, $2.2 \mathrm{~km}$ away from the SP 272 , on the road that links it to Tarabaí.

Illite and smectite are the most frequent clay minerals in the Bauru Basin. Kaolinite, mixed layer clays (illite-smectite) and chlorite appear less frequently. Most of the identified illite is apparently of clastic origin, although sometimes it may occur as an authigenic mineral. Smectite often appears as pore-lining cement, and may be replaced by authigenic kaolinite during surface processes (Fernandes et al. 1994). Corrensite has also been found in the Araçatuba Formation in pore lining (Figure 4c). These secondary clay minerals were formed probably between the sedimentation and initial diagenetic processes under conditions of little water circulation and/or a semi-arid climate.

The suprabasaltic Neocretaceous sequence reached the initial stages of mesodiagenesis (Fernandes et al. 1994). The main diagenetic transformations included mechanical compaction, incipient chemical compaction, pressure solution of unstable 

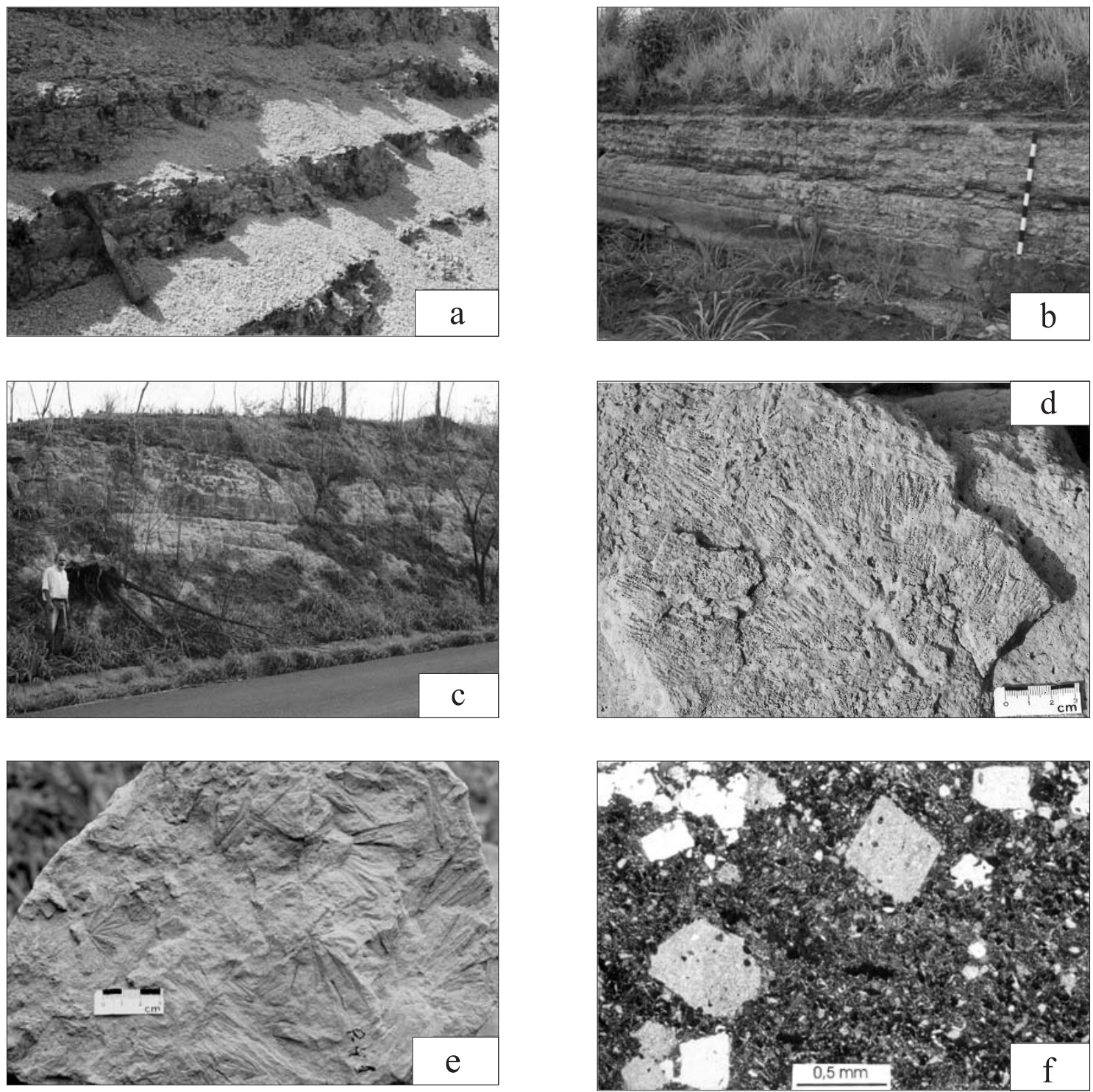

Fig. 3 (photos) - a) A common aspect in Araçatuba Formation: parallel bedding units of very fine sandstones and siltstones, with characteristic greenish-gray color. Location: SP 425 highway, km 348.7; close to the Piacatu entrance, Aguapeí river valley (UTM: 542015/7602721). b) Araçatuba Formation: very fine sandstones and siltstones, in tabular strata with parallel bedding. Location: SP 300 highway, km 548.5, near the Araçatuba city (UTM: 541659/7655764). Scale bar: 1 meter. c) Sandy bodies of sigmoidal shape, observed on the Araçatuba Formation's border areas. Location: south of Novo Horizonte, Tietê river valley, SP 333 highway, around km 223. d) Gypsite molds found a few centimeters above a root casts level. Araçatuba Formation, SE of Novo Horizonte. Location: SP 304 highway, km 412 (UTM: 686993/7619892). e) Gypsite molds. Araçatuba Formation. Sample collected in the Guararapes region. Instituto de Geociências of Universidade de São Paulo collection. f): Poikilotopic dolomite or calcite (pseudomorph). Thin section of carbonatic crust sample, Araçatuba Formation. Location: SP 300 highway, km 548.5, close to Araçatuba (UTM: 541659/7655764). Crossed polars. 

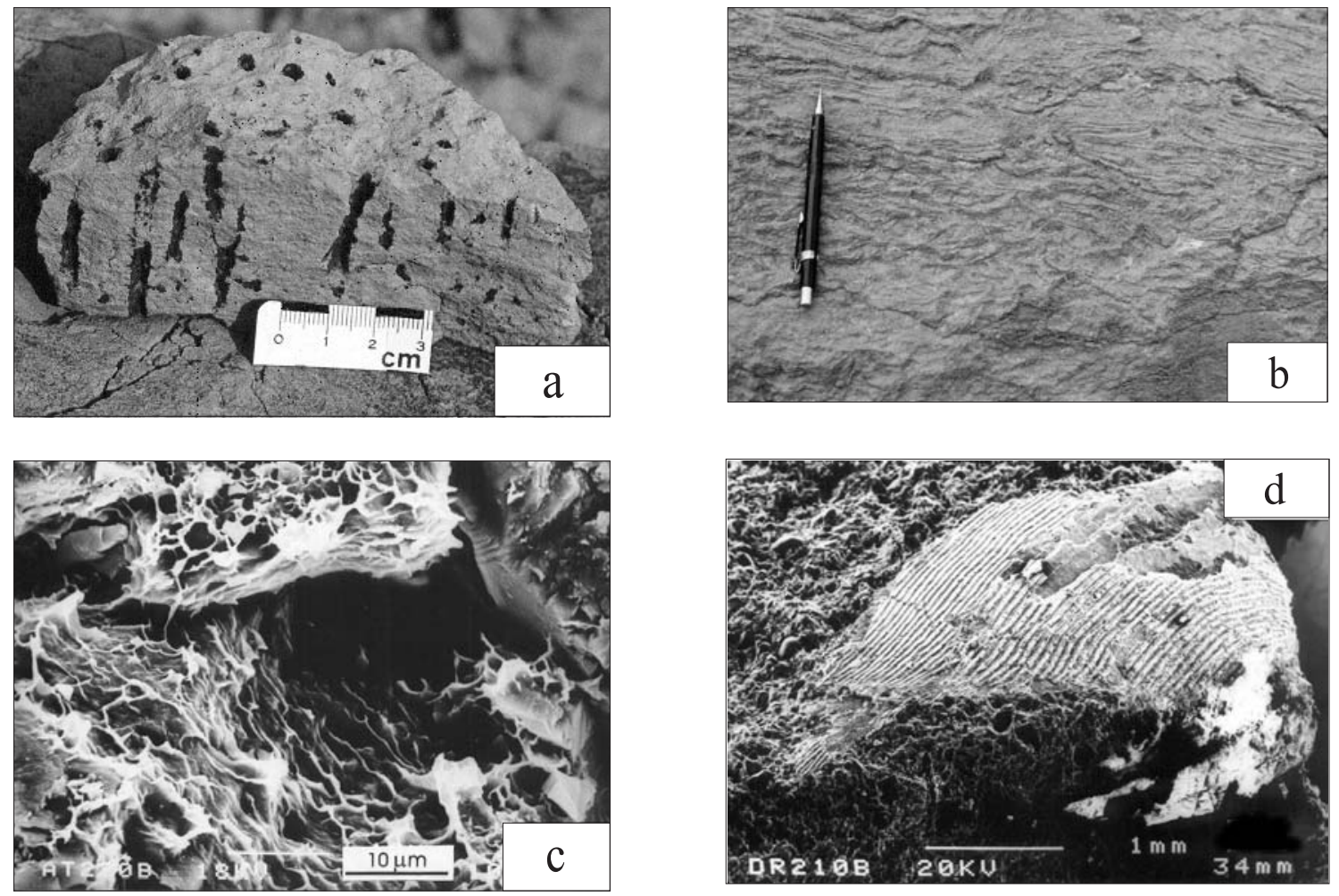

Fig. 4 (photos) - a) Root casts 3D view, Araçatuba Formation. Location: SP 304 highway, close to km 412, SE of Novo Horizonte (UTM: 686993/7619892). b) Dish structures. Outcrop situated on the Araçatuba and Vale do Rio do Peixe formations transition zone. (SP), Location: SP 321 highway, around km 472, Itajobi (UTM: 702382/7641240). c) Pore linning corrensite, Araçatuba Formation. SEM Image. Location: SP 425 highway, km 348.7; close to entrance to Piacatu (UTM: 542015/7602721). d) Bioclast (conchostraca?) in massive siltstone, Araçatuba Formation. SEM image. Location: Alfredo Marcondes-SP 294 road, km 72.2, north of Flora Rica (UTM: 462963/7608162).

mineral grains, clay mineral authigenesis, and poikilotopic carbonate cementation.

\section{FOSSIL CONTENT}

The Araçatuba Formation contains very few fossils. Mezzalira (1974) recorded the occurrence of conchostraca molds and Fernandes (1998) found conchostraca in a sample taken from a road cut of Alfredo Marcondes highway - SP 294, km 72.2, north of Flora Rica (Figure 4d). Vertical tubular features in mudstones were also found and interpreted as being root casts (Figure 4a). They reach a maximum diameter of $0.5 \mathrm{~cm}$ and the lengths vary from 10 to $30 \mathrm{~cm}$, topped by flat surfaces. They can be observed on the highways SP 300, km 548.5 (Araçatuba), SP
425, km 292.9 (Penápolis), Alfredo Marcondes SP 294, km 72.2 (north of Flora Rica) and SP 304, around $\mathrm{km} 412$.

\section{TYPE-SECTION}

The Araçatuba designation was mentioned as being lithofacies by Suguio et al. (1977) and corresponded to parts of the Santo Anastácio and Vale do Rio do Peixe units (Fernandes and Coimbra, 1998) but was also known as a formation (e.g. Suguio 1981). In the first type-section informally proposed for the unit, Barcelos (1984) presented the Araçatuba unit as an Adamantina Formation member. The author located the section in a road cut of the highway BR 153, close to the right bank of the Tietê 
River. This place however presents itself in unverifiable conditions. In its place, a reference section was postulated in the highway SP 300 (figures $3 \mathrm{~b}$ and 5), in a road cut located near Araçatuba (km 548.5; UTM: 541659/7655764). Complementary sections include road cuts in the highway SP 425,

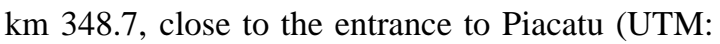
542015/7602721), in the Aguapeí River valley, and in the highway SP 333, km 224 (close to Promissão Dam). In the last one, bodies of sigmoidal geometry can be observed (Figure 3c), thereby completing the characteristics indicated for the Araçatuba Formation.

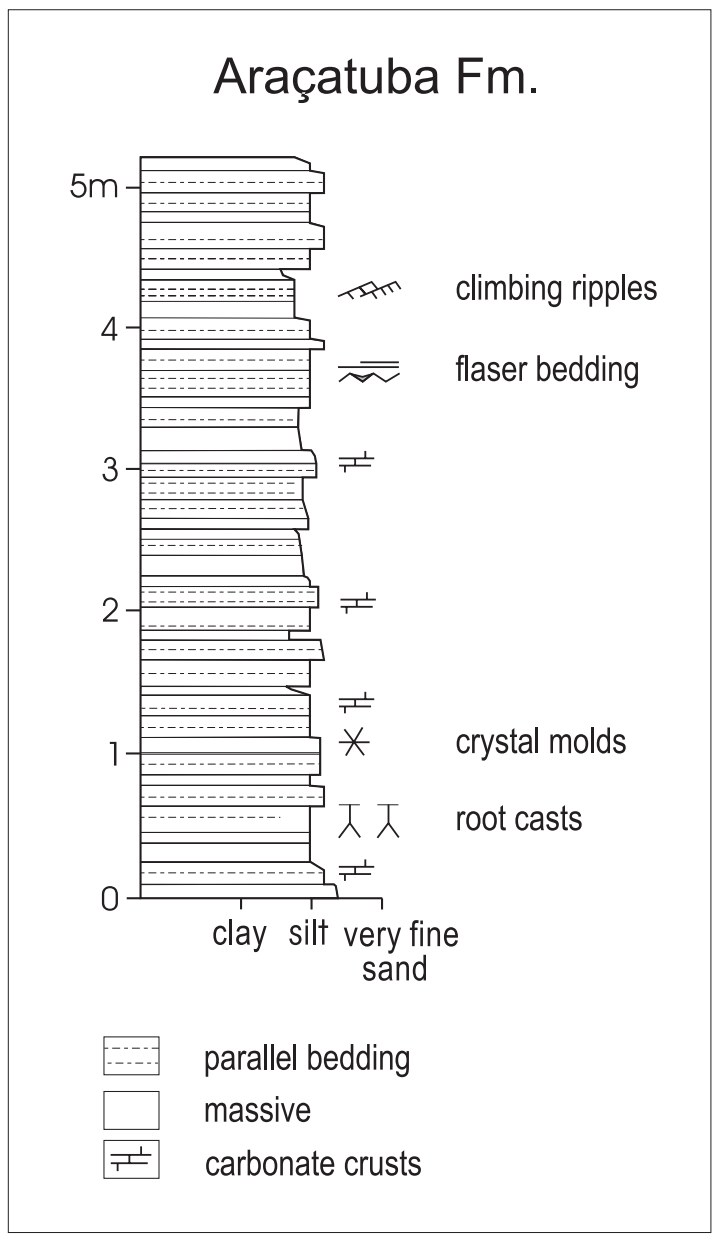

Fig. 5 - Araçatuba Formation type-section. Location: SP

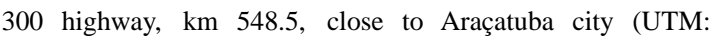
541659/7655764).

\section{POST-BASALTIC SEQUENCE AND ARAÇATUBA FORMATION AGES}

The post-basaltic sequence, the Araçatuba Formation included, was formed in the Upper Cretaceous Coniacian-Maastrichtian interval, which has been demarcated by: a) vertebrate fossil ages (Huene 1939), b) age of Taiúva analcimites, volcanic rocks intercalated in the Neocretaceous sequence (Coutinho et al. 1982), and c) correlation with some sedimentation stages in the Santos Basin (Pereira et al. 1986).

\section{STRATIGRAPHIC RELATIONSHIPS}

The Araçatuba Formation lies directly over the Serra Geral Formation basalts. It interdigitates laterally and vertically with the Vale do Rio do Peixe Formation that overlays them regionally (Figure 6). This positioning indicates a gradual transgression by aeolian sediments that progressed until the filling of the former inner swamp. Though well defined and rugged, the contact between the Vale do Rio do Peixe and Araçatuba formations is flat and devoid of erosional features. This characteristic is recurring and can be observed in several places where the units alternate upwards prior to their ingression in the domain of the Vale do Rio do Peixe Formation. The two formations may be seen positioned in normal stratigraphic juxtaposition, that is: the Vale do Rio do Peixe settled over Araçatuba (SP 379, Ibirá, entrance to São Benedito district; highway Potirendaba - Nova Aliança, around 3.5 km from Nova Aliança; and at the entrance to Nova Aliança). Less frequently they may simulate a stratigraphic inversion (SP 300, km 548.5; and highway Potirendaba-Nova Aliança, around $5 \mathrm{~km}$ from Nova Aliança). On its border zone, the Araçatuba unit is exposed in valleys where the Vale do Rio do Peixe Formation occurs in water divisors, as can be verified, for example, in the highway SP 425 between kms 314 and 325 .

In a restricted way, swampy conditions also occurred south of the main area of the Araçatuba deposits, in the domain of the Vale do Rio do Peixe Formation. Sparse and restricted exposures of grayishgreen siltstones are described in the surroundings 


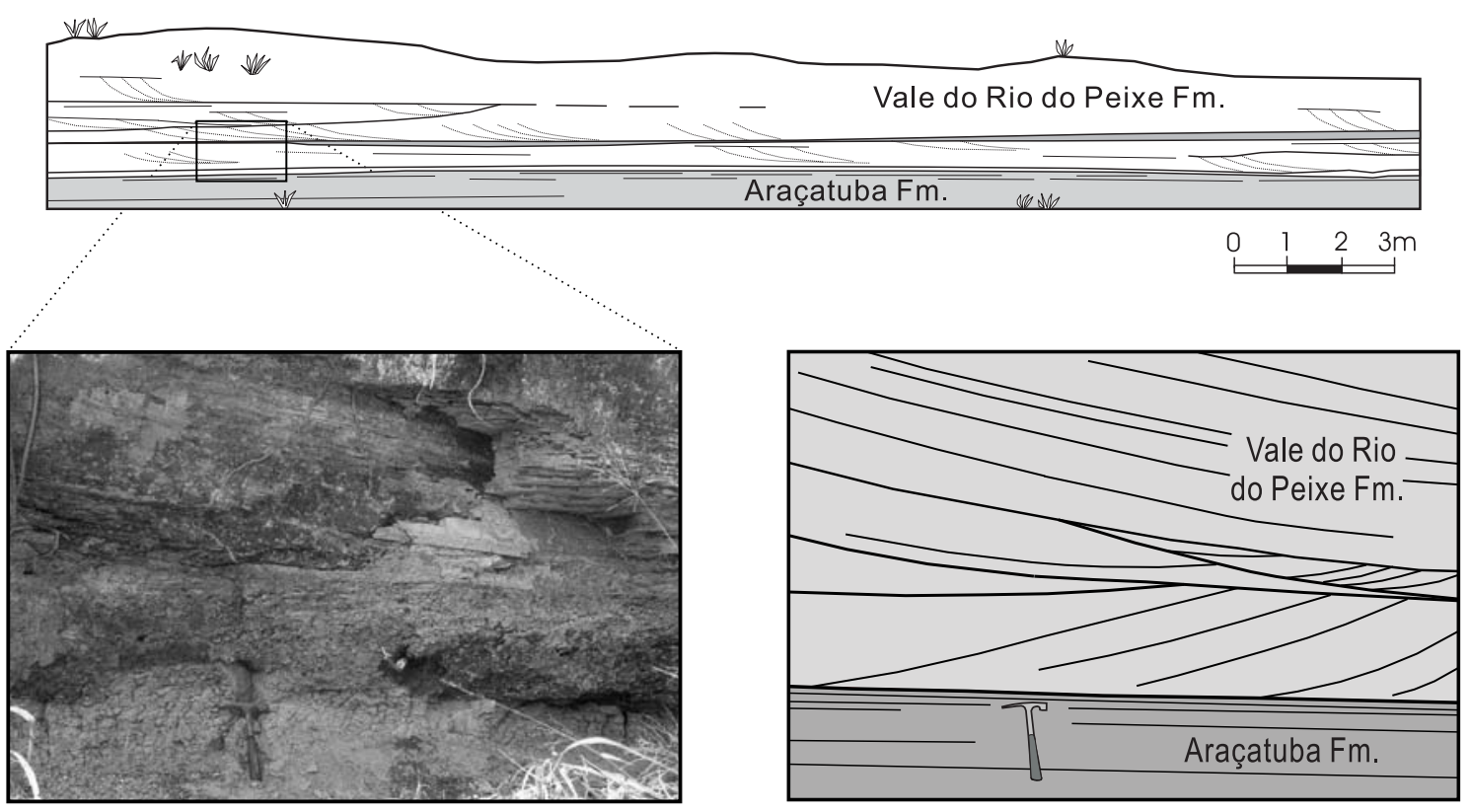

Fig. 6 - Contac between Araçatuba and Vale do Rio do Peixe formations: evidence of the Araçatuba paleoswamp silting by eolian dunes. Location: SP 425 highway, around km 329, close to Clementina (UTM:556841/7613565).

of: 1) Tarabaí (Presidente Prudente SW; $2.2 \mathrm{~km}$ to the SP 272, on the highway linking it to Tarabaí), 2) Flora Rica (Dracena SE, Alfredo Marcondes highway - SP 294, km 72.2), 3) Itajobi (São José do Rio Preto SE, on the road cut of highway SP 321,

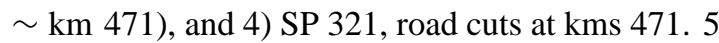
and 472. Such occurrences are regionally circumscribed by the aeolian deposits of the Vale do Rio do Peixe Formation, at stratigraphic and, probably, chronological positions that are slightly higher than the exposures in the Araçatuba region.

The Vale do Rio do Peixe Formation is the most extensive unit of the Neocretaceous succession and is present on the entire eastern part of Bauru Basin. Along the medium valleys of the Tietê, Aguapeí and São José dos Dourados rivers the Vale do Rio do Peixe Formation surrounds and overlies the contemporary Araçatuba Formation. The geological contact is, as a general rule, gradual and recurring, a stratigraphic aspect that is probably due to the contemporaneous nature of the Araçatuba and Vale do
Rio do Peixe units. In the transition zone, the sandstones are usually massive, exhibit a sub-horizontal bedding and less sorting than similar rocks in the interior zone. Their colors range from brown to greenish-gray (e.g. on Highway SP 419, km 22; Nipoã-Planalto Highway, at $13 \mathrm{~km}$ from Nipoã, Turiúba-Macaubal highway, at $\sim 16 \mathrm{~km}$ from Turiúba, Macedônia-Fernandópolis road, $\sim \mathrm{km} 114$ and São João de Iracema-General Salgado High-

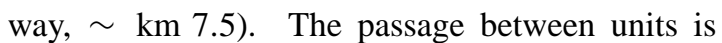
sometimes abrupt and happens at intervals of a few meters, where the recurring contact can best be seen. It is probable that such structural appearance is due to oscillations of the swamp borders, a movement that ceased only after the total superposition of the Vale do Rio do Peixe Formation (see Figure 6). Such evolution may be seen, for example, in outcrops at highway SP $300 \mathrm{~km} 548.5$ (outskirts of Araçatuba city), highway SP 425, close to km 329; highway Potirendaba - Nova - Aliança, about $5 \mathrm{~km}$ from Nova Aliança and highway SP 300, km 575). The con- 
tacts exhibited by these outcrops are subhorizontal and non-erosive. The evidence suggests that the silting of the Araçatuba swamp proceeded in a drying palustrine environment.

\section{PALEOCURRENTS}

The prevailing depositional processes in the swamp, mainly in its interior, were those of decantation. Sedimentary flow structures are uncommon in the unit. At the marginal zones of the Araçatuba Formation inclined surfaces between sandy bodies with sigmoid perfil, can eventually be observed (Figure $3 \mathrm{c}$ ). These bodies appear to have a tendence to progress toward the interior, which is the dip azimuth of inclined bedding. They probably represent sandy marginal lobes around the Araçatuba swamp. Although in small number, the surface attitudes tend to west-southwest directions, which might be interpreted as a record of the advance of aeolian border sandy lobes, during dry phases. It must be emphasized that this trend coincides with paleowinds that shaped small dunes and adjacent sand beds in the Vale do Rio do Peixe unit (Fernandes and Coimbra 1999).

A comparatively large amount of mudstone intercalations have been observed in the Vale do Rio do Peixe Formation, west of the Araçatuba Formation area. It suggests a more frequent exposure of the water table on that part of the basin. It is believed that the loess deposits, represented by silty lithofacies, were possibly retained in those damper areas. On the other hand, indications of water flowing from east or south of the Araçatuba Formation are very scarce. So, it is conceivable that the accumulated water had flowed in mainly from western or northern banks. A high frequency of wadi stream deposits would then be expected in the upper part of the Vale do Rio do Peixe Formation at the basin west side (Mato Grosso do Sul).

\section{FACIES ASSOCIATIONS AND DEPOSITIONAL SETTING}

Swamp deposits in the Araçatuba Formation are composed of two facies associations (Table I): siltstones in tabular beds (FM) and sigmoidal sandy lenses (SL). The FM association forms deposits inside the swampy area, whereas SL refers to accumulations in the border zone. The sedimentation took place in a large endorheic area of swampy, shallow and stagnant waters. In the upper part of the Araçatuba unit an increased number of outcrops favor the exposition of vestigial small-sized vegetation, as well as saline crusts and crystal molds.

Isolated sandy lenses (SL) appear in the border areas among poorly defined beds of siltstone. Apparent convoluted stratification can be occasionally found (SP 425, km 292.9, entrance to Penápolis city). These features suggest deposition and sliding of border deposits in paludal areas. The process creates small deltaic lobes and aeolian dunes fluidized by phreatic level oscillations along the swamp borders. It has been verified that there is a relative increase of the fine sand fraction towards the Araçatuba Formation periphery, where a transition zone to the Vale do Rio do Peixe Formation presumably existed. This passage probably consisted of the interface swamp border-eolian sand sheets, with wadis (e.g. road cut in BR 153, $\mathrm{km} \mathrm{187.8).}$ Examples of this peculiar facies association can be observed on the road cuts of SP $300(\mathrm{~km}$ 475.8), SP 300 ( $\mathrm{km} \mathrm{478.5),} \mathrm{BR} 153$ (km 112.5), Novo Horizonte-Sales (around km 424, Urupês), and SP 379 (Ibirá, São Benedito District).

It can be concluded that the Araçatuba Formation was erected by deposits of paludal origin, the Araçatuba swamp, accumulated in a wide flat inner area of sandy sheets (the Vale do Rio do Peixe Formation).

In swampy zones, the exposure of sediments to a more arid climate caused precipitation of carbonate and, eventually, sulphate (gypsum) during the drying-up of residual saline lakes (playa lakes). The present physiographic environment of the Pantanal Matogrossense could parallel the old Araçatuba deposition scenery in as much as the surrounding border of the Pantanal is covered by sediments deposited in zones of low regional declivity (around $1 \mathrm{~m} / \mathrm{km}$, Boggiani and Coimbra 1996). The facies 
TABLE I

Lithofacies associations of the Araçatuba Formation (After Fernandes 1998).

\begin{tabular}{|c|c|c|}
\hline Facies associations & Siltstone tabular beds (FM) & $\begin{array}{l}\text { Sandy sigmoidal lenses (SL) } \\
\text { (subordinated) }\end{array}$ \\
\hline $\begin{array}{l}\text { Lithofacies } \\
\text { (Miall 1996) }\end{array}$ & $\mathrm{Fm}, \mathrm{Fl}, \mathrm{Fr}, \mathrm{Fmc}, \mathrm{Sr}$ & $\mathrm{Sm},(\mathrm{Sp})$ \\
\hline $\begin{array}{l}\text { Lithological } \\
\text { constitution }\end{array}$ & $\begin{array}{l}\text { clay siltstone and very fine sandstone; } \\
\text { gray-green to light gray, hue and rose } \\
\text { tinted alteration; moderate to poor sorting }\end{array}$ & $\begin{array}{l}\text { very fine sandstone } \\
\text { gray color; frequent carbonate } \\
\text { cement }\end{array}$ \\
\hline Geometry & $\begin{array}{l}\text { tabular beds with non-erosive limits; } \\
\text { Decimeter thick units (up to } 1 \text { meter) }\end{array}$ & $\begin{array}{l}\text { lenticular, non-erosive limits; } \\
\text { centimetric to decimetric thikness }\end{array}$ \\
\hline $\begin{array}{l}\text { Sedimentary } \\
\text { structures }\end{array}$ & $\begin{array}{l}\text { predominantly massive; mud cracks, } \\
\text { parallel lamination (top), root casts, worm } \\
\text { tubes, crystal molds, climbing ripple cross } \\
\text { lamination }\end{array}$ & $\begin{array}{l}\text { massive to internally sigmoidal } \\
\text { stratification }\end{array}$ \\
\hline Interpretation & swamp interior deposits & sandy lobe deposits \\
\hline Observation sites & $1,2,3,4,5$ & $3,7,5,8,9$ \\
\hline $\begin{array}{c}\text { Additional } \\
\text { observations }\end{array}$ & $\begin{array}{l}\text { crystal molds: } \mathbf{1 ,} \mathbf{2}, \mathbf{6} ; \text { mud cracks, } \\
\text { climbing ripples: } \mathbf{2}, \mathbf{4} \text {; root casts: } \mathbf{1 , 3 , 7 , 6}\end{array}$ & $\begin{array}{l}\text { massive or with low angle } \\
\text { sigmoidal bedding, sometimes } \\
\text { twisted/convolute lamination } \\
\text { (area borders) }\end{array}$ \\
\hline
\end{tabular}

Outcrop locations: 1) SP 300 Highway, km 548.5; close to Araçatuba (UTM: 541659/7655764), 2) SP 461, km 40.1; entrance to Brejo Alegre (UTM: 581787/7661465), 3) SP 425 Highway, km 292.9; close to Penápolis city (UTM: 588893/7629187), 4) $2.2 \mathrm{~km}$ from SP 272, on the road that links it to Tarabaí (UTM: 439779/7536244), 5) SP 425 Highway, km 348.7; close to the Piacatu entrance (UTM: 542015/7602721), 6) SP 304 (km 412) (UTM: 686993/7619892), 7) Alfredo Marcondes Highway - SP 294, km 72.2; north of Flora Rica (UTM: 462963/7608162), 8) Potirendaba-Nova Aliança road, 5 km from Nova Aliança (UTM: 651997/7677077), 9) BR 153 Highway, km 112.5; close to the SP 304 intersection (UTM:636783/7665499).

associations and frequent evidences of exposition and desiccation, point towards sedimentation in shallow water of relatively high salinity. The absence of preserved vegetal and animal remains strengthens that interpretation. However, Batezelli et al. (1999) advocate a lacustrine environment for the Araçatuba deposits.

\section{THE FORMER ARAÇATUBA SWAMP AND THE EVOLUTION OF THE BAURU BASIN}

\section{A) The Basin Framework}

The filling of the Bauru Basin may have occurred in the course of slow and constant mechanical subsidence. This idea is corroborated by the lack of any significant tectonic dislocation and also by the gen- eral NNE gutter shape of the basin that coincides with the thickest basalt zones. The generating process to the main space for the sedimentation was a mechanical subsidence that followed the tectonic inherited structures imprinted in the substratum and therefore gave opportunity for the filling and evolution of the basin. Even some of the present lows on the basalt top, such as the depressed zone where the Araçatuba Formation developed, correspond to the original relief of the substratum (Figure 7), since they perfectly fit the lithofacies limits. The depression along the west border follows a straight line in the NNE direction. This is the same structural direction associated to probable silicification events occurred in the meridional part of the basin (Fer- 


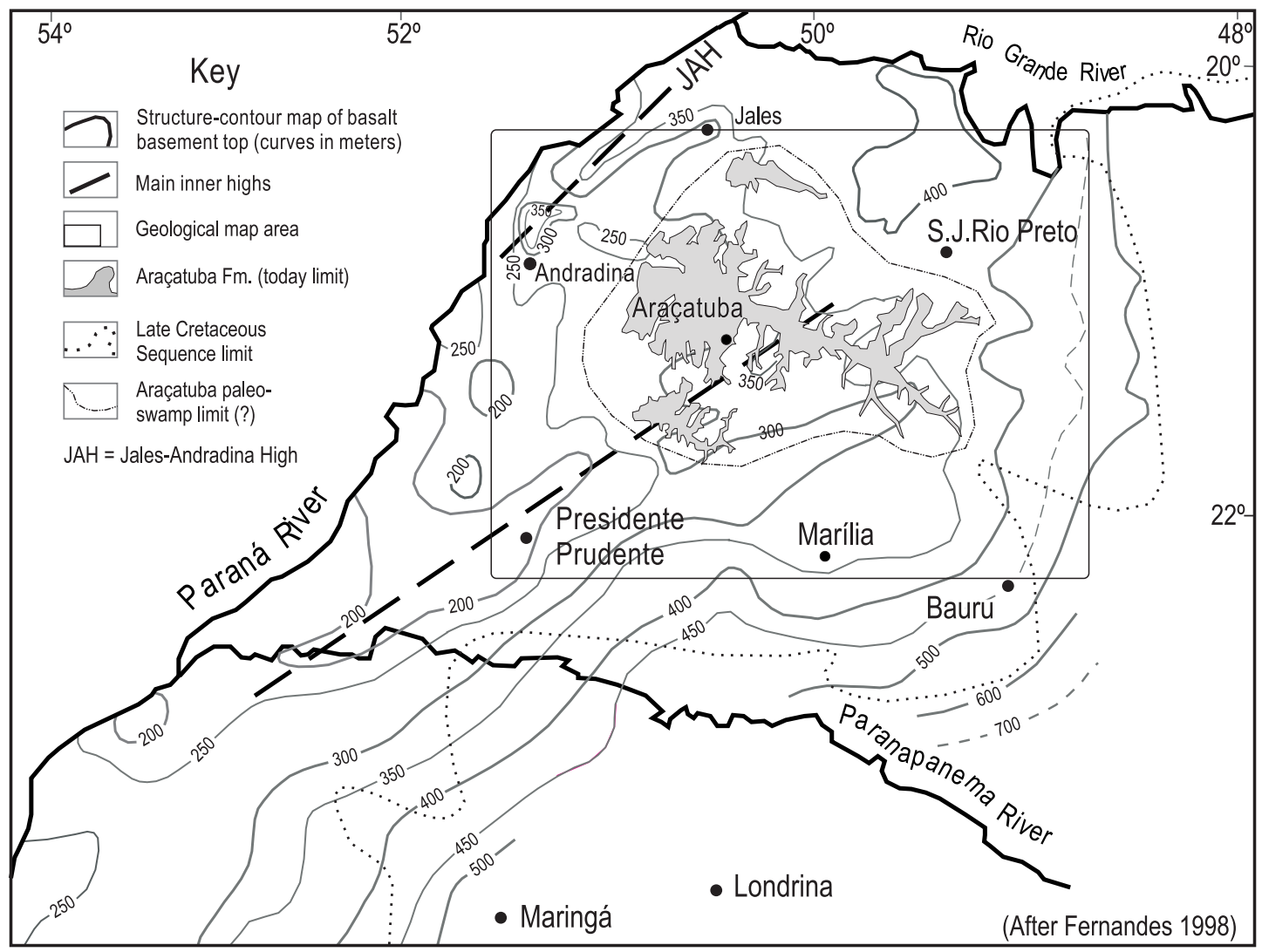

Fig. 7 - Map of the top of Serra Geral Formation: the Bauru Basin basement. The Araçatuba depressed zone and its westernmost limit parallel the Jales-Andradina High direction.

nandes et al. 1993), which is parallel to the basin's main axis and to one of the substratum crests, called the Jales-Andradina High (Fernandes 1998). The western limit of the Araçatuba Formation follows that crest direction. The top of the basaltic lava flows remained exposed for millions of years until it was buried by the sediments carried from the basin borders. The absence of basal rudaceous deposits or significant erosional features suggests that the original basement surface was flat on account of the tabular shape of the basalt strata, and may have suffered further leveling by mechanical weathering during periods of semiarid climate. The current relief of the basalt basement displayed by structural contours is the end product of different subsidence rates and post-sedimentary tectonic movements.

At the time of the Bauru Basin filling, signifi- cant tectonism and associated alkaline magmatism took place at the basin borders. The more active periods apparently coincided with the exchanging time between two sedimentation stages, the first is represented by a desertic tract system that included the initial entry and accumulation of sandy sediments on the basalt substratum. Sedimentation processes followed the setting of effective conditions of accumulation, which happened during the slow regional subsidence started in the Upper Cretaceous. The basal beds settled as monotonous sand sheets and intercalated dunes and loess deposits formed during a hot and dry climate (Figure 8). Inside this huge sand sea, a relatively depressed and damp region of endorheic characteristics, was covered by very fine sand and silt in a paludal environment (Araçatuba Formation). Aeolian sediments of the Vale do Rio 
do Peixe Formation were initially deposited at the same time and during the same environmental conditions but ended by silting the whole depression. This set of systems is dominantly aeolian but contains a fluvial component restricted to eventual flows generated by torrential rains (wadis), which were probably more intense on the northwest border. In the present study the wadis deposits are regarded as part of the Vale do Rio do Peixe Formation. The second filling stage of the basin took place in the presence of a larger amount of water still in the semi-arid climate (fluvial-aeolian system tract), present throughout the sedimentation of the Marília, São José do Rio Preto and Presidente Prudente formations.

\section{Araçatuba Fm. depositional setting}

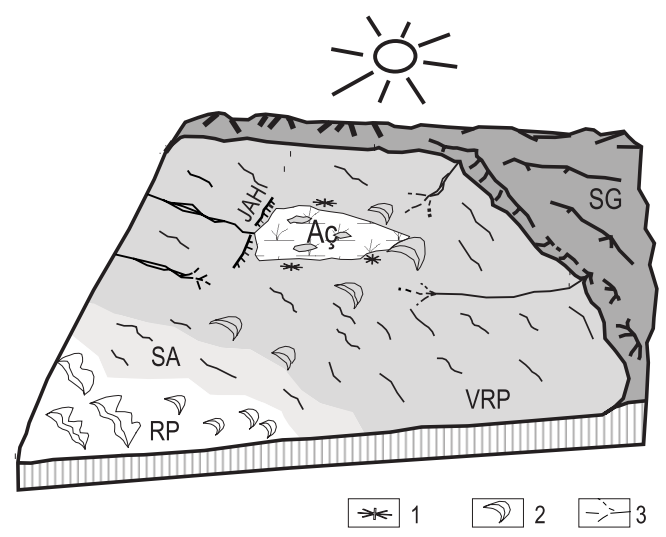

KEY: 1: saline crusts and crystals, 2: eolian dunes, 3: wadi, SG: Serra Geral Fm. (basement), Aç: Araçatuba Fm., VRP: Vale do Rio do Peixe Fm., SA: Santo Anastácio Fm., RP: Rio Paraná Fm., JAH: Jales-Andradina High.

Fig. 8 - Hypothetical paleogeographic model for Araçatuba sedimentation: a swampy area of the Bauru Basin initial sedimentation.

Sediments originating from the north and east borders (Coimbra 1976) were slowly carried toward the interior of the Bauru Basin by the wind, which formed broad sand sheets and loess blankets, associated to fields of medium sized dunes. The increase in dryness towards the southwest, as well as the very fine sand transported by SW winds, set up the conditions for the birth of the great Caiuá Desert in the inner part of the basin (Fernandes and Coimbra 2000b).

\section{B) Sedimentation and Silting of the}

\section{AraÇATUba SWAmp}

During the initial stage of filling of the Bauru Basin a broad and monotonous blanket of sand associated to average-sized dunes and loess deposits gradually buried the basalt basement. Low fluvial activity was at that time restricted to floods of desert torrents (wadis).

The area encompassed by the Araçatuba Formation coincides with a basement sag on the surface. The original bed rock relief promoted endorheic conditions inside the basin, where a large swampy area (Araçatuba Swamp) was then installed in a semi-arid region. A negative water balance suggests that the water accumulated in this depressed semi-arid zone should have been derived from the humid west or northwest fluviatile areas, beyond the swamp limits. It is suggestive that a relative increase of mudstone and wadi deposits have been detected in the eastern area (Mirante do Parapanema and especially, Andradina). An approximately similar status can be visualized in the present-day Pantanal Matogrossense. Although semi-arid conditions prevail in most of the Pantanal region, periodical floods have been recorded, fed by torrents coming from higher marginal parts where rains are more intense, mainly to the north at the Paraguay river source (Boggiani and Coimbra 1996).

The westernmost limit of the swamp deposits is a straight line matching the Jales-Andradina High (Figure 7), a positive structural high that must have served as the old swamp west border. It is conceivable that the building up of the swamp had its origin in the barrier set up by the structural high and consequent exposure of the phreatic level. The constant supply of aeolian sediments that initially erected dunes and border banks, would finally dry up and bury the original depressed area. The basal layers of the sedimentary succession filled the con- 
cavities in the lower basement and eliminated any less expressive floor ruggedness.

Until the final drying up of the swampy areas, salt water bodies of growing salinity had been formed. They grew constantly bigger in spite of occasional dry periods. Molds of fiber radial gypsum crystals, root casts, vestiges of small size vegetation, mud cracks and carbonate cement were all formed in the transition epoch. Variations of the probably shallow water table should have caused alternation of saline lacustrine and aeolian environments. The earliest aeolian dunes that transgressed the swamp limits were occasionally flooded and mobilized by the rising of the water level. Small sand lobes intermingled with water-settled tabular beds were therefore formed, containing some evidence of sand dune fluidization.

During the initial sedimentation phase, the Araçatuba swamp was definitively silted by aeolian deposits of the Vale do Rio do Peixe Formation. This silting may have been the result of intensification of the interior dryness for purely climatic reasons and/or caused by barring of watercourses coming from the west and northwest. In the latter case, it is likely that the basement high, coincident with the rectilinear western border of the Araçatuba Formation, corresponds to a geographic obstacle of tectonic origin that was active during the initial filling of the Bauru Basin. The pebbly lithofacies, which occurs a couple of kilometers to the west of Sete Lagoas (MS), would possibly correspond to hammada deposits linked to the basement high.

\section{ACKNOWLEDGMENTS}

The authors would like to express their gratitude to FAPESP, the São Paulo State Research Support Foundation for financial support (FAPESP proceeding 93/4524-9) and to Prof. Dr. José Moacyr Vianna Coutinho for his critical reading and English text correction.

\section{RESUMO}

A Bacia Bauru (Cretáceo Superior), acumulou uma seqüência sedimentar continental essencialmente arenosa.
Numa fase inicial desértica, o seu substrato basáltico foi soterrado por extensa e monótona cobertura de areias eólicas com intercalações subordinadas de depósitos de loesse. O relevo original do substrato favoreceu a formação de uma drenagem regional endorrêica, sob clima semi-árido, propiciando assim condições de formação do Paleopantanal Araçatuba. Os depósitos paludiais (Formação Araçatuba) constituem estratos tabulares de siltitos e arenitos de cor cinza claro esverdeado típica, eventualmente cimentados por carbonato de cálcio. Moldes e pseudomorfos de cristais de gipsita e dolomita foram identificados na unidade. Aparentemente, estão associados com gretas de ressecação, marcas de raízes e intervalos com laminação tipo climbing ripple, que indicam ambiente de águas salinas rasas e relativamente calmas, submetidas a fases de exposição subaérea e ressecação. Nos limites da área de ocorrência da Formação Araçatuba, as unidades arenosas podem exibir feições sigmóides e estratificação contorcida, comuns em depósitos deltaicos marginais. A Formação Araçatuba é contornada e posteriormente encoberta por depósitos eólicos da Formação Vale do Rio do Peixe.

Palavras-chave: Araçatuba, cretáceo, Bauru, (pântano, paludial, continental).

\section{REFERENCES}

Almeida FFM. 1964. Fundamentos geológicos do relevo paulista. Bol Inst Geogr Geol 41: 169-263.

Almeida MA, Stein DP, Melo MS, Bistrichi CA, Ponçano WL, Hasui Y and Almeida FFM. 1980. Geologia do Oeste Paulista e áreas fronteiriças dos estados de Mato Grosso do Sul e Paraná. In: Congresso Brasileiro de Geologia, 31, Camboriú. Anais... Camboriú, Sociedade Brasileira de Geologia, 1980. v.5, p. 2799-2812.

Batezelli A, Perinotto JAJ, Etchebehere MLC, Fúlfaro VJ AND SAAd AR. 1999. Redefinição litoestratigráfica da unidade Araçatuba e da sua extensão regional na Bacia Bauru, estado de São Paulo, Brasil. In: Simpósio SOBRE o CRETÁCEO do BRASIL, 5./SiMPOSIO SOBRE El CRETÁcico DE AmÉrICA DEL Sur, 1, Serra Negra (SP). Boletim... Rio Claro, Universidade Estadual Paulista; 195-200.

BARCELOS JH. 1984. Reconstrução paleogeográfica da sedimentação do Grupo Bauru baseada na sua re- 
definição estratigráfica parcial em território paulista e no estudo preliminar fora do Estado de São Paulo. Rio Claro, 1984. 190p. Tese (Livre-Docência) Universidade Estadual Paulista, Instituto de Geociências e Ciências Exatas.

Boggiani PC and Coimbra AM. 1996. A planície e os pantanais. In: ANTAS PTZ AND NAscimento ILS. 1996. Tuiuiu. Sob os céus do Pantanal. São Paulo: Empresa das Artes, p.18-23.

Brandt Neto M. 1977. Estratigrafia da Formação Bauru na região do baixo Tietê. São Paulo, 1977. 74p. Dissertação de Mestrado, Universidade de São Paulo, Instituto de Geociências.

Coimbra AM. 1976. Arenitos da Formação Bauru: estudo de áreas fonte. São Paulo, 1976. 2v. Dissertação de Mestrado, Universidade de São Paulo, Instituto de Geociências.

Coutinho JMV, Coimbra AC, Brandt Neto M AND RochA GA. 1982. Lavas alcalinas analcimíticas associadas ao Grupo Bauru $(\mathrm{Kb})$ no Estado de São Paulo, Brasil. In: Congreso Latinamericano dE Geologia, 5, Buenos Aires. Actas... Buenos Aires, Servicio Geologico Nacional, v.2; 185-196.

Etchebehere MLC, SaAd AR, Taddeo JSA AND Hellmeister JR. Z. 1991. Moldes de cristais salinos no Grupo Bauru, Estado de São Paulo: implicações econômicas e paleoclimáticas. Geoc 10: 101-117.

FERNANDEs LA. 1998. Estratigrafia e evolução geológica da parte oriental da Bacia Bauru (Ks, Brasil). São Paulo, 216p. Tese (Doutorado) Universidade de São Paulo, Instituto de Geociências. (3 mapas).

Fernandes LA And CoImbra AM. 1994. O Grupo Caiuá (Ks): revisão estratigráfica e contexto deposicional. Rev Bras Geoc 24: 164-176.

Fernandes LA And Coimbra AM. 1996. A Bacia Bauru (Cretáceo Superior, Brasil). An Acad Bras Cienc 68: 195-205.

FERnANDES LA AND CoImbra AM. 1998. Estratigrafia e evolução geológica da Bacia Bauru (Ks, Brasil). In: Congresso Brasileiro de Geologia, 40, Belo Horizonte. Anais... Belo Horizonte, Sociedade Brasileira de Geologia, p.101.

Fernandes LA And Coimbra AM. 1999. Paleocorrentes da parte oriental da Bacia Bauru (Ks, Brasil). In: Simpósio SObre o CRETÁceO do Brasil, 5./SIMPOSIO SOBRE El CRETÁCICO DE AmÉRICA DEL SUR, 1,
Serra Negra (SP). Boletim... Rio Claro, Universidade Estadual Paulista, p.51-57.

Fernandes LA And CoImbra AM. 2000a. Revisão estratigráfica da parte oriental da Bacia Bauru (Neocretáceo). Rev Bras Geoc 30: 723-734.

Fernandes LA And Coimbra AM. 2000b. The Late Cretaceous Caiuá Desert (Bauru Basin, Brazil). In: International Geological Congress, 31, Rio de Janeiro (Brasil). Abstracts... (cd-rom, General Symposia, 3.6).

Fernandes LA, Coimbra AM and Brandt Neto M. 1993. Silicificação hidrotermal neocretácea na porção meridional da Bacia Bauru. Rev Inst Geol 14: 19-26. 1993.

Fernandes LA, Coimbra AM, Brandt Neto M and Desenzi ALG. 1994. Argilominerais do Grupo Caiuá. Rev Bras Geoc 24: 90-96.

Huene F von. 1939. Carta de F. von Huene ao Dr. Euzébio de Oliveira. Min Metal, Rio de Janeiro, v.4 n.22 p. 190 .

KING LC. 1956. A geomorfologia do Brasil oriental. Rev Bras Geogr 18: 147-265.

Mezzalira S. 1974. Contribuição ao conhecimento da estratigrafia e paleontologia do Arenito Bauru. Bol Inst Geogr Geol 51: 1-163.

Mezzalira S, Azevedo AAB, Tominaga LK, PresSinotTi MMN AND Massoli M. 1981. Léxico estratigráfico do Estado de São Paulo. Bol Inst Geogr Geol 5: 1-161.

Miall AD. 1996. The geology of fluvial deposits. Sedimentary facies, basin analysis and petroleum geology. New York: Spriger-Verlag, 1996. 582p.

Pereira MJ, Barbosa CM, Agra J, Gomes JB, Aranha LGF, Saito M, Ramos MA, Carvalho MD, StamATO M AND BAgNi O. 1986. Estratigrafia da Bacia de Santos: análise das seqüências, sistemas deposicionais e revisão litoestratigráfica. In: CoNGRESSo Brasileiro de Geologia, 34, Goiânia. Anais... Goiânia, Sociedade Brasileira de Geologia. v.1: 6579.

SoARes PC, LANDim PMB, Fúlfaro VJ and Sobreiro Neto AF. 1979. Ensaio de caracterização estratigráfica do cretáceo no Estado de São Paulo. In: SImPósio Regional de Geologia, 2, Rio Claro. Boletim de Resumos... Rio Claro, Sociedade Brasileira de Geologia/Núcleo SP: 30-31. 
SoAres PC, Landim PMB, Fúlfaro VJ ANd Sobreiro Neto AF. 1980. Ensaio de caracterização do Cretáceo no Estado de São Paulo: Grupo Bauru. Rev Bras Geoc 10: 177-185.

Suguio K. 1981. Fatores paleoambientes e paleoclimáticos e subdivisão estratigráfica do Grupo Bauru. In: Mesa Redonda: A Formação Bauru no Estado de São Paulo e Regiões Adjacentes, São Paulo. Coletânea de trabalhos e debates... São Paulo, Sociedade Brasileira de Geologia/Núcleo SP: 15-26.
Suguio K, Fúlfaro VJ, Amaral G and Guidorzi LA. 1977. Comportamentos estratigráficos e estrutural da Formação Bauru nas regiões administrativas 7 (Bauru), 8 (São José do Rio Preto) e 9 (Araçatuba) no Estado de São Paulo. In: Simpósio de Geologia ReGIONAL, 1, São Paulo. Atas... São Paulo, Sociedade Brasileira de Geologia/Núcleo SP: 231-247. 